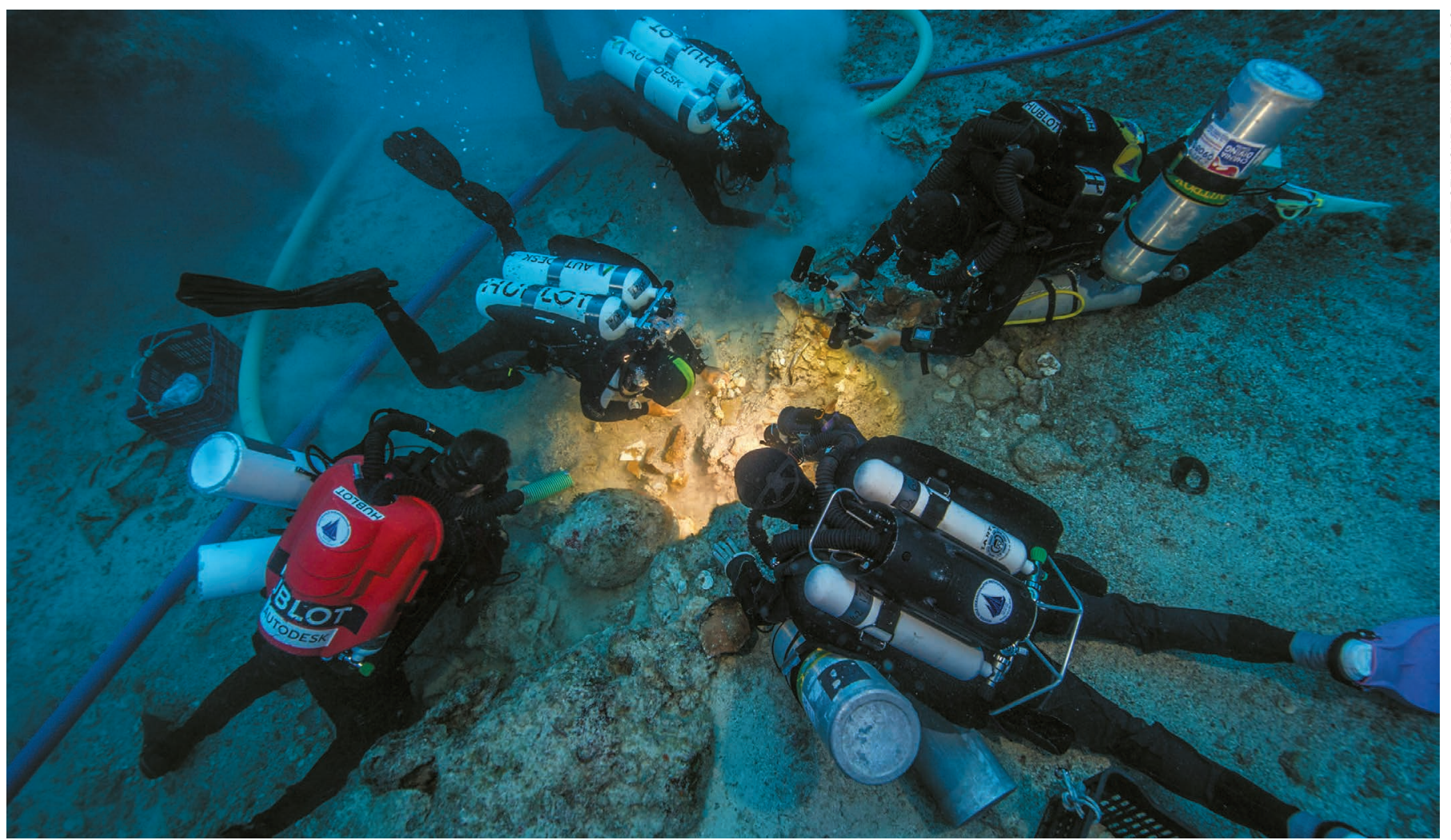

Divers examine human bones excavated from the Antikythera shipwreck.

\title{
Human skeleton found on famed Antikythera wreck
}

\section{Two-thousand-year-old bones could yield first DNA from an ancient shipwreck victim.}

\section{BY JO MARCHANT, ANTIKYTHERA, GREECE}

$\mathrm{H}$ annes Schroeder snaps on two pairs of blue latex gloves, then wipes his hands with a solution of bleach. In front of him is a large Tupperware box full of plastic bags that each contain sea water and a piece of red-stained bone. He lifts one out and inspects its contents as several archaeologists hover behind, waiting for his verdict. They're hoping he can pull off a feat never attempted before - DNA analysis on someone who has been under the sea for 2,000 years.

Through the window, sunlight sparkles on cobalt water. The researchers are on the tiny Greek island of Antikythera, a 10-minute boat ride from the wreckage of a 2,000-year-old merchant ship. Discovered by sponge divers in 1900, the wreck was the first ever investigated by archaeologists. Its most famous bounty to date has been a surprisingly sophisticated clockwork device that modelled the motions of the Sun, Moon and planets in the sky - dubbed ${ }^{1}$ the 'Antikythera mechanism'.

But on 31 August this year, investigators made another groundbreaking discovery: a human skeleton, buried under around half a metre of pottery sherds and sand. "We're thrilled," says Brendan Foley, an underwater archaeologist at Woods Hole Oceanographic Institution in Massachusetts, and co-director of the excavations team. "We don't know of anything else like it."

Within days of the find, Foley invited Schroeder, an expert in ancient-DNA analysis from the Natural History Museum of Denmark in Copenhagen, to assess whether genetic material might be extracted from the bones. On his way to Antikythera, Schroeder was doubtful. But as he removes the bones from their bags he is pleasantly surprised. The material is a little chalky, but overall looks well preserved. "It doesn't look like bone that's 2,000 years old," he says. Then, sifting through several large pieces of skull, he finds both petrous bones - dense nuggets behind the ear that preserve DNA better than other parts of the skeleton or the teeth. "It's amazing you guys found that," Schroeder says. "If there's any DNA, then from what we know, it'll be there."

Schroeder agrees to go ahead with DNA extraction when permission is granted by the Greek authorities. It would take about a week to find out whether the sample contains any DNA, he says: then perhaps a couple of months to sequence it and analyse the results.

For Schroeder, the discovery gives him the chance to push the boundaries of ancient-DNA studies. So far, most have been conducted on samples from cold climates such as northern Europe. "I've been trying to push the application of ancient DNA into environments where people don't usually look for DNA," he says. (He was part of a team that last year published the first Mediterranean ancient genome, of a Neolithic individual from Spain ${ }^{2}$.)

Foley and the archaeologists, meanwhile, are 
elated by the chance to learn more about the people on board the first-century $\mathrm{BC}$ ship, which carried luxury items from the eastern Mediterranean, probably intended for wealthy buyers in Rome.

\section{RARE DISCOVERY}

The skeleton discovery is a rare find, agrees Mark Dunkley, an underwater archaeologist from the London-based heritage organization Historic England. Unless covered by sediment or otherwise protected, the bodies of shipwreck victims are usually swept away and decay, or are eaten by fish. Complete skeletons have been recovered from younger ships, such as the sixteenth-century English warship the Mary Rose and the seventeenth-century Vasa in Sweden. Both sank in mud, close to port. But "the farther you go back, the rarer it is", says Dunkley.

Only a handful of examples of human remains have been found on ancient wrecks, says archaeologist Dimitris Kourkoumelis of the Greek Ephorate of Underwater Antiquities, who collaborates with Foley. They include a skull found inside a Roman soldier's helmet near Sardinia, and a skeleton reportedly discovered inside a sunken sarcophagus near the Greek island of Syrna (although the bones disappeared before the find could be confirmed).

In fact, the best-documented example is the Antikythera wreck itself: scattered bones were found by the French marine explorer Jacques Cousteau, who excavated here in 1976. Argyro Nafplioti, an osteoarchaeologist at the University of Cambridge, UK, concluded that the remains came from at least four individuals, including a young man, a woman and a teenager of unknown sex ${ }^{3}$.

At the wreck site, only broken pots now remain on the sea floor - the sponge divers recovered all artefacts visible on the seabed in 1900-01. But Foley thinks that much of the ship's cargo may be buried under the sediment. His team, including expert technical divers and members of the Greek archaeological service, relocated and mapped the 50-metre-deep site before beginning their own excavations in 2014. They have found items such as wine jars, glassware, two bronze spears from statues, gold jewellery and table jugs used by the crew (see 'Ancient bounty'). The divers have also recovered ship components including enormous anchors and a teardrop-shaped lead weight, found in June, that may be the first known example of what ancient texts describe as a 'war dolphin' - a defensive weapon carried by merchant vessels to smash hostile ships.

The skeleton uncovered in August consists of a partial skull with three teeth, two arm bones, several rib pieces and two femurs, all apparently from the same person. Foley's team plans further excavations to see whether
ANCIENT BOUNTY

An underwater shelf near the Greek island of

Antikythera marks where a ship sank in the first

century BC. In 1900, it became the first shipwreck

to be investigated by archaeologists. Among the

site's finds are a sophisticated clockwork device

- the 'Antikythera mechanism' — and, most

recently, a human skeleton.

Selected finds o 1976 ○ 2014-16

Location of 1900-01 finds not recorded
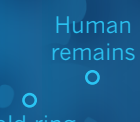

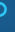
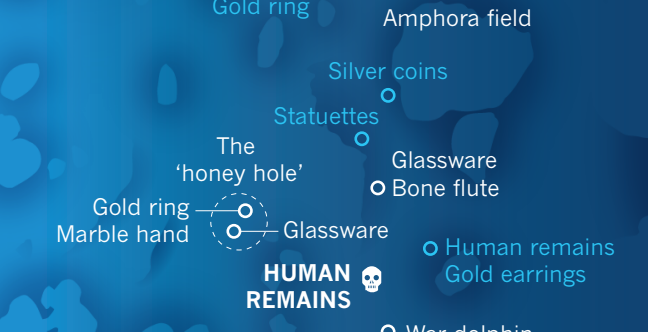

o War dolphin

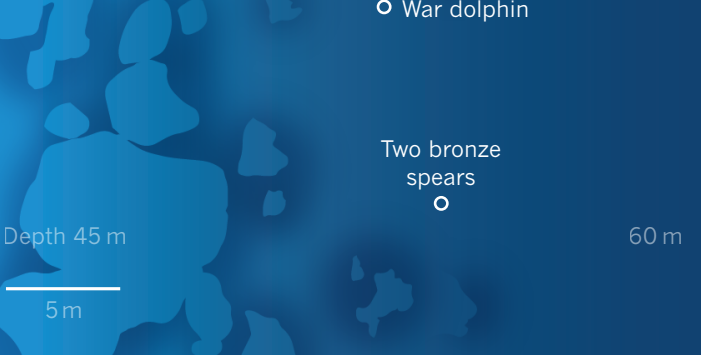

more bones are still under the sand.

That so many individuals have been found at Antikythera - when most wrecks yield none - may be partly because few other wrecks have been as exhaustively investigated. But the researchers think it also reveals something about how the ship sank. This was a huge vessel for its time, perhaps more than 40 metres long, says Foley, with multiple decks and many people on board. The wreck is close to shore, at the foot of the island's steep cliffs. He concludes that a storm smashed the ship against the rocks so that it broke up and sank before people had a chance to react. "We think it was such a violent wrecking event, people got trapped below decks."

\section{MEDITERRANEAN MYSTERY}

The individuals found at Antikythera could be from the crew, which would probably have consisted of 15-20 people on a ship this size. Greek and Roman merchant ships also commonly carried passengers, and sometimes slaves. One reason people get trapped inside shipwrecks is if they are chained, points out Dunkley. "The crew would be able to get off relatively fast. Those shackled would have no opportunity to escape." Intriguingly, the recently discovered bones were surrounded by corroded iron objects, so far unidentified; the iron oxide has stained the bones amber red.

Schroeder says that because ancient underwater remains are so rare, DNA analysis on such samples using state-of-the-art techniques has barely been tried. (Analyses were conducted on skeletons from the Mary Rose and the Vasa, but specialists no longer see those methods - based on amplifying DNA using a method called PCR - as reliable, because it is too difficult to distinguish ancient DNA from modern contamination.) Exceptions include analyses on 8,000-year-old wheat from a submerged site off the English coast (although these results have been questioned because the DNA did not show the expected age-related damage ${ }^{4}$ ), and mitochondrial DNA from a 12,000-yearold skeleton found in a freshwater sinkhole in Mexico ${ }^{5}$.

Finding undisturbed remains such as those at Antikythera is crucial because it offers the opportunity to extract any DNA in the best possible condition. Previously salvaged bones are not ideal for analysis because they have often been washed, treated with conservation materials or kept in warm conditions (all of which can destroy fragile DNA), or handled in a way that contaminates them.

Schroeder guesses from the skeleton's fairly robust femur and unworn teeth that the individual was a young man. As well as confirming the person's gender, DNA from the Antikythera bones could provide information about characteristics from hair and eye colour to ancestry and geographic origin. In the past few years, modern genome sequences have revealed that genetic variation in populations mirrors geography, says Schroeder. He and others are now starting to look at how ancient individuals fit on that map, to reconstruct past population movements. Would the shipwreck victim look more Greek-Italian or Near Eastern, he wonders?

Over dinner, the researchers decide to nickname the bones' owner Pamphilos, after a name found neatly scratched on a wine cup from the wreck. "Your mind starts spinning," says Schroeder. "Who were those people who crossed the Mediterranean 2,000 years ago? Maybe one of them was the astronomer who owned the mechanism."

1. Freeth, T. et al. Nature 444, 587-591 (2006).

2. Olalde, I. et al. Mol. Biol. Evol. 32, 3132-3142 (2015)

3. Nafplioti, A. in The Antikythera Shipwreck: The Ship, the Treasures, the Mechanism (eds Kaltsas, N. et al.) 57-60 (Natl Archaeol. Mus., Athens, 2012).

4. Weiss, C. L., Dannemann, M., Prüfer, K. \& Burbano, H. A. elife http://dx.doi.org/10.7554/ eLife.10005 (2015)

5. Chatters, J. C. et al. Science 344, 750-754 (2014).

\section{CORRECTION}

The News story 'Nobel Assembly deals with scandal' (Nature 537, 289-290; 2016)

erroneously gave Stockholm as the location for all of the Nobel prize ceremonies. 